\title{
Polluting Emissions from Incineration and Waste Installations
}

\author{
MARINA CRISTINELA TUCUREANU1', CARMEN OTILIA RUSANESCU'*, LARISA PURDEA* \\ University Polytechnic, Faculty of Biotechnical Systems Engineering, 313 Splaiul Independentei, 060042, Bucharest, Romania

\begin{abstract}
Currently, waste generates numerous environmental effects: air pollution, surface water and groundwater. In this paper we study the concentrations of polluting emissions resulting from the incineration of waste, such as $\mathrm{NO}_{x^{\prime}} \mathrm{CO}, \mathrm{NMVOC}, \mathrm{SO}_{x^{\prime}}, \mathrm{TSP}, \mathrm{PM}$ 10, PM 2,5, Pb, Cd, $\mathrm{Hg}, \mathrm{As}, \mathrm{Cr}, \mathrm{Cu}, \mathrm{Ni}, \mathrm{Zn}, \mathrm{HCB}$, by comparing
\end{abstract} \\ emission values for several types of waste
}

Keywords: incinerator, waste, air pollution

The composition of industrial waste varies considerably. Industrial waste includes unwanted hazardous / chemical wastes (acids and alkalis, halogenated and other potentially toxic compounds, fuels, oils and greases, used filter materials, animal waste and food) [8, 10,11, 13]. Industrial waste sources include chemical plants, refineries, light and heavy industries, and so on $[1-4,9,14,16,17]$.

Incineration of urban waste is used to reduce waste disposal by storing them or recovering energy by burning. Incineration must comply with technical regulations to avoid adverse effects on human health and the environment $[4,28,29-43]$.

The concept of sustainable development requires the selection and application of the most appropriate and available new energy resources, including the application of technologies that focus on waste incineration [5]. The use of municipal waste for energy production involves environmental problems if appropriate preventive pollutants are not used for combustion gases [19-26, 44].

The incineration of municipal waste leads to the formation of a combustion gas which includes, among other emissions, heavy metals (mercury emissions) [6, 18].

The residue resulting from incineration requires a longer storage time in special landfills. The cost of storing the hazardous waste resulting from incineration is high [7].

Industrial waste are incinerated to reduce its volume, to reduce its storage costs and to prevent the release of chemicals and toxic substances into the environment [ 8 , 30-36]. In some cases, energy is recovered from the combustion of waste either to obtain heat or to produce electricity [2].

Industrial waste incinerators are likely to be more significant emitters of dioxins, cadmium and mercury than many other sources, depending on the type of waste, combustion efficiency and reduction level [2].

Partial combustion of sludge can lead to emissions of incomplete combustion intermediates, including toxic organic compounds such as dioxins (EPA, 1979, 1982, 1984, 1994) [9].

Pollutants released from sludge incineration are: sulfur oxides $\left(\mathrm{SO}_{\mathrm{x}}\right)$, nitrogen oxides $\left(\mathrm{NO}_{\mathrm{x}}\right)$, volatile organic compounds, carbon monoxide ( $\mathrm{CO}$ ), carbon dioxide $\left(\mathrm{CO}_{2}\right)$ and nitrogen oxide $\left(\mathrm{N}_{2} \mathrm{O}\right)$. However, sewage sludge incinerators can emit significant amounts of major pollutants (metals, $\mathrm{CO}, \mathrm{NO}_{x^{\prime}} \mathrm{SO}_{2}$, uncharged hydrocarbons) [2].

Nitrogen and sulfur oxide emissions are primarily the result of oxidation of nitrogen and sulfur in sludge [10].
Sulfur oxides are the result of the oxidation of sulfur, in the form of organic and inorganic combinations, in fossil fuels. The concentration of sulfur in fuels can vary widely, depending on the type of fuel and the extraction technology $[14,15]$.

The main reactions leading to the formation of $\mathrm{SO} 2$ are (1) and (2), they lead to the appearance of oxygen-free atoms, very chemically active and which will intervene in the subsequent reactions:

$$
\begin{aligned}
& \mathrm{S}+\mathrm{O}_{2} \rightarrow \mathrm{SO}_{2} \\
& \mathrm{SO}+\mathrm{OH} \rightarrow \mathrm{SO}_{2}+\mathrm{H}
\end{aligned}
$$

Atomic nitrogen radicals react with molecular nitrogen, the overall oxidation reaction is form

$$
\mathrm{N}_{2}+\mathrm{O}_{2} \rightarrow 2 \mathrm{NO}
$$

Emissions of volatile organic compounds vary greatly depending on the type of incinerator and its operation [2, $6]$.

Carbon monoxide occurs when the available oxygen is insufficient for a complete firing or when the air levels are too high, resulting in lower combustion temperatures [10, 2].

Emissions of polycyclic organic compounds from the incineration of sewage sludge, may result from combustion of carbonaceous material from sludge and from the combustion of additional incinerator fuel [2].

Waste incineration is one of the main sources of emissions of dioxins, emissions whose concentration depends on their reduction options [2].

In developed countries between $40-80 \%$ of municipal solid waste are eliminated, while in developing countries this rate has reached 60-90\%. More commercial businesses generate enormous quantities of residual substances, which are typically loaded with toxic heavy metals such as $\mathrm{Cd}, \mathrm{Cu}, \mathrm{Cr}, \mathrm{As}, \mathrm{Pb}$ [9].

Heavy metals are not biodegradable and tend to accumulate in living organisms, causing various problems. When these metals reach the limit of contamination, they become very harmful to humans and the environment [9]. Of these heavy metals, $\mathrm{Pb}$ is considered highly toxic to plants and cumulative poison to other beings. This is an important environmental and health problem worldwide [9].

Municipal, industrial and medical solid waste are the collected materials from households, companies and hospitals. They are composed of a mixture of combustible and non-combustible materials (paper, plastics, food waste, glass).

\footnotetext{
*emaoil: rusanescuotilia@gmail.com; larisa.purdea@gmail.com
} 
Waste can be incinerated for: reduce volume, to save storage space costs, to recover energy from their combustion.

\section{Experimental part}

Materials and methods

Solid waste that is improperly disposed can create a breeding ground for pathogenic microorganisms and disease, and can cause public discontent due to inappropriate smell. May cause contamination of surrounding soil, groundwater, surface water and may create fire hazards, physical hazards and harmful effects $[11,12]$.

The NOx, CO, NMVOC, SOx, TSP, PM 10, PM 2,5, Pb, Cd, $\mathrm{Hg}, \mathrm{As}, \mathrm{Cr}, \mathrm{Cu}, \mathrm{Ni}, \mathrm{Zn}, \mathrm{HCB}$ pollutants were analyzed for the limit values specified in the legislation.

For this study, the following categories of waste were considered: industrial waste, municipal waste, medical waste.

Modern incineration plants and older plants that have been refurbished have a wide range of emission reduction equipment to reduce the impact of waste incineration: acid gases, heavy metals and dioxin emissions [13].
To reduce emissions from incinerators, textile filters, electrostatic precipitators, wet scrubbers, semi-dry scrubbers or spray absorption systems, dry injection systems, adsorption using activated carbon were used [13] .

Table 1 shows the emission factors for waste incineration when there are emission reduction equipment. (particle/ active carbon trapping) [2].

\section{Results and discussions}

Depending on the incineration plant and the type of waste, differences in pollutantemissions may occur. Figure 1 shows graphically the variation of the concentrations of pollutants from municipal, medical, industrial waste, it is observed that the highest concentration is the NMCOV pollutantresulting from the incineration of industrial waste.

In figure 2, the variation of heavy metal pollutant concentrations is plotted graphically, the highest concentrations are found for $\mathrm{Pb}, \mathrm{Hg}, \mathrm{Cr}$ and $\mathrm{Cu}$. These concentrations resulted from the incineration of medical waste.

Figure 3 shows graphically the variation of PM10, PM 2.5 pollutant concentrations, it can be seen that the highest concentration of PM10 results from the incineration of municipal waste.

\begin{tabular}{|c|l|l|l|l|l|}
\hline $\begin{array}{c}\text { Current } \\
\text { Number }\end{array}$ & Pollutant & Municipal Waste & Industrial Waste & Medical Waste & Unit \\
\hline 1 & $\mathrm{NO}_{\mathbf{x}}$ & 1.8 & 0.87 & 1.4 & $\mathrm{Kg} / \mathrm{Mg}$ waste \\
\hline 2 & $\mathrm{CO}$ & 0.7 & 0.07 & 2.8 & $\mathrm{Kg} / \mathrm{Mg}$ waste \\
\hline 3 & $\mathrm{NMCOV}$ & 0.02 & 7.4 & 0.7 & $\mathrm{Kg} / \mathrm{Mg}$ waste \\
\hline 4 & $\mathrm{SO} \times$ & 0.4 & 0.047 & 1.4 & $\mathrm{Kg} / \mathrm{Mg}$ waste \\
\hline 5 & $\mathrm{TSP}$ & 0.3 & 0.01 & 0.5 & $\mathrm{Kg} / \mathrm{Mg}$ waste \\
\hline 6 & $\mathrm{PM} \mathrm{10}$ & 0.23 & 0.007 & 0 & $\mathrm{Kg} / \mathrm{Mg}$ waste \\
\hline 7 & $\mathrm{PM} 2.5$ & 0.15 & 0.004 & 0 & $\mathrm{Kg} / \mathrm{Mg}$ waste \\
\hline 8 & $\mathrm{~Pb}$ & 0.8 & 1.3 & 13 & $\mathrm{~g} / \mathrm{Mg}$ waste \\
\hline 9 & $\mathrm{Cd}$ & 0.1 & 0.1 & 1 & $\mathrm{~g} / \mathrm{Mg}$ waste \\
\hline 10 & $\mathrm{Hg}$ & 1.1 & 0.056 & 8 & $\mathrm{~g} / \mathrm{Mg}$ waste \\
\hline 11 & $\mathrm{As}$ & 0.01 & 0.016 & 1.3 & $\mathrm{~g} / \mathrm{Mg}$ waste \\
\hline 12 & $\mathrm{Cr}$ & 0.185 & 0.3 & 4.7 & $\mathrm{~g} / \mathrm{Mg}$ waste \\
\hline 13 & $\mathrm{Cu}$ & 0.093 & 3 & 2.6 & $\mathrm{~g} / \mathrm{Mg}$ waste \\
\hline 14 & $\mathrm{Ni}$ & 0.12 & 21 & 0.4 & $\mathrm{~g} / \mathrm{Mg}$ waste \\
\hline 15 & $\mathrm{Zn}$ & 0.9 & 0.002 & 0 & $\mathrm{~g} / \mathrm{Mg}$ waste \\
\hline 16 & $\mathrm{HCB}$ & 0.002 & $\mathrm{~g} / \mathrm{Mg}$ waste \\
\hline
\end{tabular}

Table 1

EMISSIONS VALUES FOR MUNICIPAL, INDUSTRIAL AND MEDICAL WASTE [2]

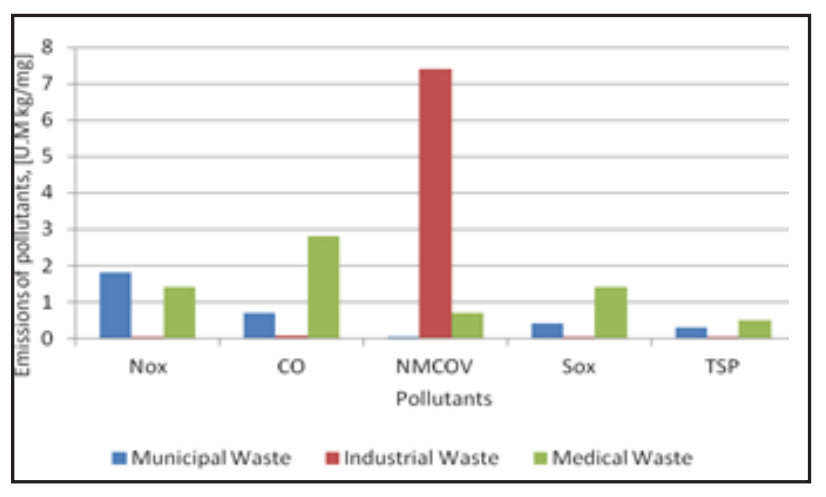

Fig. 1 Concentrations of pollutants $-\mathrm{NO}_{x^{\prime}} \mathrm{CO}, \mathrm{NMCOV}, \mathrm{SO}_{x^{\prime}} \mathrm{TSP}$

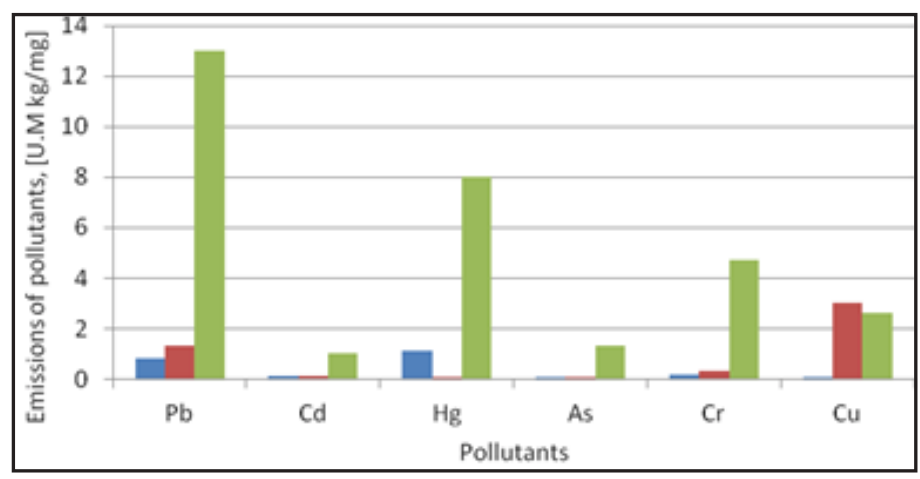

m Municipal Waste $=$ Industrial Waste $=$ Medical Waste

Fig. 2 Concentrations of Pollutants $\mathrm{Pb}, \mathrm{Cd}, \mathrm{Hg}, \mathrm{As}, \mathrm{Cr}, \mathrm{Cu}, \mathrm{Ni}$. 


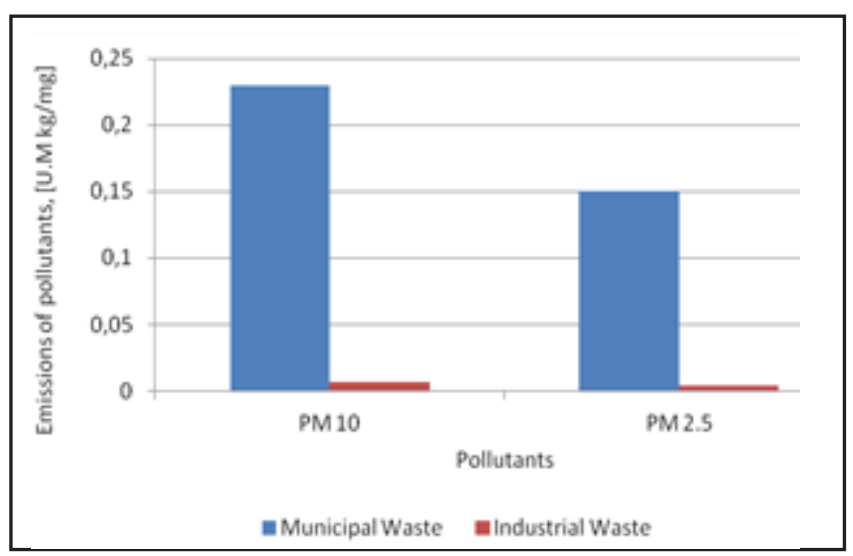

Fig. 3 Concentrations of pollutants PM 10, PM 2,5

\section{Conclusions}

The reason for the study was to observe how the emission concentrations can be influenced by the types of incinerated waste. Based on this study, it can be concluded that the most polluting pollutants result from the incineration of municipal and medical waste. Depending on the incineration plant and the type of waste, emission differences may occur. Through these data we can understand the importance of pollutant capture filters. The effects on the environment and the population due to incinerators are mainly related to emissions released into the atmosphere, organic matter losses and other biomasscontaining materials [27]. The overall environmental of waste incineration depends on a multitude of factors, such as fuel quality, energy efficiency of plants and the replaced energy source. The incineration directive makes it possible to minimize emissions (such as heavy metals, dioxins) from incineration.

\section{References}

1. DULCEA, D., IONEL, I., PASCU, L. F., Chem. Abs., RCBUAU 66, 8, 1083 - 1256, ISSN 0034-7752, 66, 8, 2015.

2. WENBORN, M., COLEMAN, P., WOODFIEL, M., RENTZ, O., OERTEL, D., EMEP/EEA Air Pollutant Emission Inventory GuideBook, 2009.

3. KUITUNEN, M. K., JALAVA, K. HIRVONEN, Environmental Impact Assessement Review, 28, 2008, p. 312-320.

4. RUSANESCU, C., O., PARASCHIV, G., RUSANESCU, M., Rev. Chim.(Bucharest), 69, no. 8, 2018, p. 2005-2011.

5. NATIONAL AGENCY FOR ENVIRONMENTAL PROTECTION, Annual Report - Status of Environmental Factors in Romania.

6. CALANTER, P., Quality - Access to Success, 3, 13, 201, p. 249-2592. 7. IONEL, I., POPESCU, F., PADURE, G., GAVRILA, T.T., Rev. Chim.(Bucharest), 60, no. 1, 2009, p. 81-85.

8. GNANDT, F., VASIU, R., LUNGU, D., $\mathrm{XI}^{\text {th }}$ International Multidisciplinary Conference with International Participation, Professor Dorin Pavel Founder of Romanian Hydro Power Engineering, 2011, p. 531-538.

9. RUSANESCU, C. O., RUSANESCU, M., ANGHELINA, F. V., Bratu, V., Romanian Reports in Physics, 68, 1, 2016, p. 278-293.

10. JINESCU, C., Mat. Plast., 51, no. 3, 2014, p. 235-240.

11. CAPSA, D., NEDEFF, V., BARSAN, N., Academic J ournal of Science, 3, 2, 2014, p. 97-106.

12. POPESCU, I., FRONTASYEVA, M., STIHI, C., CIMPOCA, Ghe., RADULESCU, C., GHEBOIANU, A., OROS, C., VLAICU, Ghe., PETRE, C., BÃNCUTÃ, I., DULAMA, I., Romanian Journal of Physics, 55, 7-8, 2010, p. 821-829.

13.UNGUREANU, G, IGNAT, G., LEONTE, E., COSTULEANU, C. L., JITAREANU, S., DONOSA, D., SOARE, E., T., SANDU, I. G., ReV. Chim.(Bucharest), 69, no. 6, 2018, p. 1585-1595.

14. RUSANESCU, C. O., RUSANESCU, M., Rev. Chim.(Bucharest), 69, 11, 2018, p. 3006-3009.

15.UNGUREANU, G., IGNAT, G., LEONTE, E., COSTULEANU, C.L., STANCIU, N., SANDU, I.G., DONOSA, D., BEJ INARIU, C., Rev. Chim. (Bucharest), 68, no. 12, 2017, p. 2941.

REV.CHIM. (Bucharest) $70 \diamond$ No. 7 • 2019

http://www.revistadechimie.ro
16. ISTRATE, M., Technologies and installations for reducing pollutant emissions, Pollution control in thermoenergetics, 2004.

17. JINESCU, V., MANEA, S.E., JINESCU, C., Rev. Chim.(Bucharest), 68, no. 4, p. 656, 2017.

18. GROS, F., URSU, A.V., DJELVEH, G., JINESCU, C., NISTOR, IL. D., JINESCU, GHE., Rev. Chim. (Bucharest), 61, no. 6, 2010, p. 590.

19. RUSANESCU C.O., POPESCU I. N., DAVID L., $3^{\text {rd }}$ International Conference on Environmental and geological science and Engineering (EG' 10), 2010, p. 175-180.

20. MURARESCU, O., PEHOIU, G., RADULESCU, C., DULAMA, I.D., TEODORESCU, S., STIRBESCU, R., M., MURATOREANU, G., Rev. Chim.(Bucharest), 69, no. 5, 2018, p. 1037-1040.

21. POPESCU, I., FRONTASYEVA, M., STIHI, C., CIMPOCA, G., RADULESCU, C., STATE, G., GHEBOIANU, A., OROS, C., CULICOV, O., BÃNCUTA, I., DULAMA, I., Romanian Reports in Physics, 63, 2011, p., 1205-1214.

22. RUSANESCU, C.O., JINESCU, C., PARASCHIV, G., BIRIS, S. ST., RUSÃNESCU, M., GHERMEC, 0., Rev. Chim. (Bucharest), 66, no. 5, 2015, p.754-757.

23. RADULESCU, C., IORDACHE, S., DUNEA, D., STIHI, C., DULAMA, I.D., Romanian J ournal of Physics, 60, 7-8, 2015, p. 1171-1182.

24. RUSANESCU, M., PURCAREA, A. A., RUSANESCU, C.O., Conference: $6^{\text {th }}$ International Conference on Management and Industrial Engineering - ICMIE, 2013, p. 395-400.

25.DUNEA, D., IORDACHE, S., RADULESCU, C., POHOATA, A., DULAMA, I. D., Romanian J ournal of Physics, 61, 7-8, 2016, p. 1354-1368.

26. KAPPEL, W., JIPA, S., ZAHARESCU, T., SETNESCU, R., OROS, C., Rev. Chim. (Bucharest)., 57, no. 3, 2006, p. 290-292.

27. RUSANESCU, M., RUSANESCU, C. O., VOICU, GHE, BEGEA, M., Rev. Chim.(Bucharest), 69, no. 7, 2018, p. 1695-1698.

28. GHERMEC, O., GHERMEC, C., DUBOVAN, S., RUSANESCU, C. 0. Environmental Engineering and Management J ournal, 12, 10, 2013, p. 2019-2023.

29. DOGARU, D., JINESCU, C., DOGARU, GHE., Rev. Chim. (Bucharest), 60, no. 8, 2009, p. 826-829.

30. CRIVINEANU, M. F., DUMITREL, G. A., PERJU, D. S., JINESCU, C., NEGREA, A., Rev. Chim. (Bucharest), 63, no. 10, 2012, p. 1051-1055 31. PATROESCU, V., JINESCU, C., COSMA, C., CRISTEA, I., BADESCU, V., STEFAN, C. S., Rev. Chim. (Bucharest), 66, no. 4, 2015, p. 537-541. 32. RUSNESCU, C.O., MURAD, E., JINESCU, C., RUSNESCU, M., Rev. Chim.(Bucharest), 69, no. 8, 2018, p. 21697-2202.

33. MUNTIANU, G., URSU, A. V., JINESCU, C., DJ ELVEH, G., NISTOR, I. D., JINESCU, G. Rev. Chim. (Bucharest), 66, no. 3, 2015, p. 295-298. 34. JINESCU, C., Mat. Plast., 51, no. 3, 2014, p. 235-240.

35. JINESCU, VALERIU V., PETRESCU, S, JINESCU, C., Rev. Chim. (Bucharest), 64, no. 6, 2013, p. 630-638.

36. RUSANESCU, C. O., RUSANESCU, M., J. Min. Metall. Sect. B-Metall., 49, 3, B, 2013, p. $353-356$.

37. DURBACA, I., Mat. Plast., 52, no. 1, 2015, p.43.

38. RODICA, L. , DULAMA, I. D., RADULESCU, C., BUCURICA, I. A., STIRBESCU, R. M., TEODORESCU, S., J ournal of Science and Arts, Year 18, No. 4(45), 2018, p. 1033-1044.

39. DESPA, V., ANGHELINA, F. V., IANCU, D., RUSANESCU, C. O., JOURNAL OF SCIENCE AND ARTS, YEAR 17, 4, 41, 2017, p. 839-852. 40. BERBECARU, A. C., COMAN G., GRADINARU, C. St., SOHACIU, M. G., PREDESCU, C., DUMITRESCU, R. E., CIUCA, S., GHERGHESCU, I. A.,Rev. Chim. (Bucharest)., 70, no. 4, 2019, p. 1132-1139.

41. SOHACIU, M. G., NICOLAE, A., GRÃDINARU, C., NICOLAE, M., U.P.B. Sci. Bull., Series B, Vol. 80, Iss. 4, 2018, p.2019.

42. RUSANESCU, C. O., RUSANESCU, M., ANGHELINA, F. V., J. Optoelectron. Adv. Mater. 15, 7-8, 2013, p. 724-729.

43. ANDREI, V.A, MALINOVSCHI, V., RADULESCU, C., IONITA, I., TOROK, G., COACA, E., MARIN, A. H., JOURNAL OF SCIENCE AND ARTS, 1, 2019, p. 185-194.

44. JIPA, S., ZAHARESCU, T., SETNESCU, R., KAPPEL, W., OROS, C., GORGHIU, L. M., Nuclear Instrumentations and Methods in Physics Research, Section B: Beam Interactions with Materials and Atoms, 265, 2007, p. 305-308.

Manuscript received: 14.12 .2018 